DOI: $10.15193 /$ zntj/2019/120/302

\author{
BEATA ŁASZKIEWICZ, PIOTR SZYMAŃSKI, \\ DANUTA KOŁOŻYN-KRAJEWSKA
}

\title{
WPLYW WYBRANYCH SZCZEPÓW BAKTERII KWASU MLEKOWEGO NA PRZYDATNOŚĆ TECHNOLOGICZNĄ I JAKOŚĆ MIKROBIOLOGICZNĄ MIĘSA DROBIOWEGO ODDZIELONEGO MECHANICZNIE
}

\author{
Streszczenie
}

Celem pracy była ocena wpływu wybranych szczepów bakterii kwasu mlekowego na przydatność technologiczną i trwałość mikrobiologiczną mięsa drobiowego oddzielonego mechanicznie (MDOM).

Materiał doświadczalny stanowiło mięso drobiowe MDOM, do którego dodano trzy szczepy bakterii kwasu mlekowego na poziomie $10^{7} \mathrm{jtk} / \mathrm{g}$ - Lactobacillus plantarum SCH1 i Lactobacillus brevis KL5 wyizolowane z surowych wędlin dojrzewających oraz Lactobacillus plantarum S21 wyizolowany z serwatki kwasowej. Wariant kontrolny nie zawierał dodatku bakterii. Farsze z MDOM przechowywano w warunkach chłodniczych i badano po 1, 4 i 7 dniach przechowywania. Zakres badań obejmował oznaczenie: ogólnej liczby drobnoustrojów, liczby mezofilnych bakterii fermentacji mlekowej, liczby Escherichia coli, liczby Enterobacteriaceae, obecności Salmonella spp., obecności Campylobacter spp. i liczby gronkowców koagulazododatnich oraz oznaczenie cech fizykochemicznych, tj. pH i potencjału oksydacyjno-redukcyjnego, zawartości azotanów (III) i (V) oraz ocenę barwy w systemie CIE L*a*b*. Zastosowanie szczepów bakterii kwasu mlekowego w farszach z mięsa drobiowego oddzielonego mechanicznie nie wpłynęło negatywnie na ich przydatność technologiczną. Zaobserwowano pozytywny wpływ Lactobacillus brevis KL5 na kształtowanie barwy surowych farszów z MDOM. Wykazano hamujący wpływ Lactobacillus plantarum SCH1 na bakterie Escherichia coli oraz Enterobacteriaceae w surowych farszach z MDOM po 4 dniach chłodniczego przechowywania. Przeprowadzone badania umożliwiają stwierdzenie, że wybrane szczepy LAB wyizolowane z produktów pochodzenia zwierzęcego wpływają hamująco na wzrost drobnoustrojów w MDOM.

Słowa kluczowe: mięso drobiowe oddzielone mechanicznie (MDOM), przydatność technologiczna MDOM, bakterie kwasu mlekowego, jakość mikrobiologiczna MDOM

Mgr inż. B. Łaszkiewicz, dr inż. P. Szymański, Zakład Technologii Mięsa i Tłuszczu, Instytut Biotechnologii Przemystu Rolno-Spożywczego im. prof. Wacława Dąbrowskiego, ul. Jubilerska 4, 04-190 Warszawa, prof. dr hab. D. Kołożyn-Krajewska, Katedra Technologii Gastronomicznej i Higieny Żywności, Wydz. Nauk o Żywieniu Człowieka i Konsumpcji, Szkoła Główna Gospodarstwa Wiejskiego w Warszawie, ul. Nowoursynowska159 C,02-776Warszawa.Kontakt: beata.laszkiewicz@ibprs.pl 


\section{Wprowadzenie}

Mięso oddzielone mechanicznie (MOM) to produkt pozyskiwany z kości zwierząt rzeźnych lub ich fragmentów bądź z tusz drobiowych (MDOM) z naturalnie przyległą tkanką miękką w postaci fragmentów mięsa chudego, tłuszczu i tkanki łącznej, które oddzielane są od kości. MOM uzyskuje się za pomocą środków mechanicznych, co prowadzi do utraty lub modyfikacji struktury włókien mięśniowych [18, 38, 43]. W praktyce przemysłowej MOM otrzymywany jest najczęściej metodą naruszającą strukturę kości i metodą nienaruszającą tej struktury. W pierwszej metodzie kości są częściowo rozdrabniane, a tkanka miękka przyległa do kości wyciskana jest pod ciśnieniem $10 \div 40 \mathrm{MPa}$ przez głowice separujące oraz sita o małej średnicy otworów. W przypadku drugiej metody mięso oddziela się bez naruszenia struktury kości za pomocą wirującego bębna z perforacją $[14,20]$.

Mięso oddzielone mechanicznie jest surowcem tańszym od mięsa wykrawanego ręcznie i powszechnie stosowanym w przetwórstwie w kraju i na świecie [8, 24].

Zastosowanie MOM w przemyśle spożywczym to $\mathrm{w}$ dużej mierze produkcja pasztetów, konserw, kiełbas drobno rozdrobnionych i homogenizowanych oraz wyrobów garmażeryjnych, np. hamburgerów czy krokietów [5, 46]. W ostatnich latach obserwuje się na świecie coraz większe spożycie mięsa drobiowego, co wiąże się ze wzrostem produkcji MDOM z kości drobiowych oraz jego wykorzystaniem w przemyśle [10].

W procesie separacji mięsa od kości następuje duże rozdrobnienie surowca, zanik struktury tkankowej oraz napowietrzenie, co sprzyja wzrostowi zanieczyszczenia mikrobiologicznego. Ponadto surowiec do produkcji mięsa drobiowego oddzielonego mechanicznie (MDOM) może zawierać stosunkowo wysoką liczbę drobnoustrojów, w tym patogennych, szczególnie z rodziny Enterobacteriaceae. W mikroflorze MOM mogą być obecne bakterie chorobotwórcze, jak: Salmonella spp., Campylobacter spp.,

Escherichia coli, Listeria monocytogenes, Yersinia enterocolitica, Staphylococcus aureus, jak również bakterie saprofityczne, głównie z rodzaju Pseudomonas, przyspieszające psucie mięsa $[8,21]$.

W badaniach Michalskiego i Pomykały $[21,36]$ wykazano w 46 partiach MDOM z krajowych zakładów przemysłowych obecność Salmonella spp. w 25 g. W 58 \% prób MDOM stwierdzono obecność beztlenowych bakterii przetrwalnikujących w $0,01 \mathrm{~g}$, w $87 \%$ prób stwierdzono obecność bakterii z grupy coli w $0,001 \mathrm{~g}$, a w $76 \%$ badanych prób były obecne gronkowce koagulazo-dodatnie w $0,1 \mathrm{~g}$.

Do najczęściej stosowanych metod utrwalania mięsa oddzielonego mechanicznie można zaliczyć mrożenie i peklowanie, jednak ich stosowanie wiąże się z pewnymi ograniczeniami. Proces mrożenia powoduje pogorszenie cech sensorycznych i technologicznych surowca [45]. Zastosowanie peklowania może być natomiast niewystarczające $\mathrm{w}$ związku z planowanymi zmianami $\mathrm{w}$ zakresie obniżania poziomu stosowania 
azotanów(III) w produkcji żywności $[12,18]$. Celowe wydaje się zatem poszukiwanie nowych, szybkich metod i sposobów jego konserwacji.

Bakterie kwasu mlekowego (ang. lactic acid bacteria, LAB) mogą mieć szerokie zastosowanie w bioprotekcji, ponieważ w naturalny sposób są w stanie zdominować mikroflorę wielu produktów spożywczych w czasie ich przechowywania [2, 25, 37]. Aktywność przeciwdrobnoustrojowa szczepów LAB przypisywana jest m.in. pozakomórkowym substancjom białkowym [37, 39]. Bakterie kwasu mlekowego są powszechnie stosowane do produkcji wędlin surowych dojrzewających. Nowym kierunkiem jest próba zastosowania LAB, m.in. Lactobacilus sakei, Lactobacilus curvatus do zwiększenia trwałości i bezpieczeństwa zdrowotnego wyrobów surowych (metki i tatara). Prowadzone są także badania nad zastosowaniem wybranych szczepów LAB w bioprotekcji wędlin parzonych plastrowanych $[4,11]$.

Mięso oddzielone mechanicznie jest surowcem o niższej jakości pod względem mikrobiologicznym, fizykochemicznym i technologicznym $\mathrm{w}$ porównaniu z mięsem wykrawanym ręcznie [3, 22]. Zastosowanie bakterii kwasu mlekowego w MOM może być alternatywą dla aktualnie stosowanych metod konserwowania lub dodatkowym elementem w technologii płotków podwyższających jego jakość $[1,18]$.

Celem pracy była ocena wpływu zastosowania wybranych szczepów bakterii kwasu mlekowego na trwałość mikrobiologiczną i przydatność technologiczną mięsa drobiowego oddzielonego mechanicznie (MDOM).

\section{Material i metody badań}

Badania przeprowadzono na mięsie drobiowym oddzielonym mechanicznie $\mathrm{z}$ korpusów kurczaków, wytworzonym w warunkach przemysłowych w separatorze (AM2C, Francja) techniką naruszającą strukturę kości (średnica otworów $1 \mathrm{~mm}$ ). MDOM transportowany był w postaci zamrożonej $\left(-18^{\circ} \mathrm{C}\right)$. Doświadczalne produkcje farszów z MDOM przeprowadzono w hali półtechnicznej Zakładu Technologii Mięsa i Tłuszczu Instytutu Biotechnologii Przemysłu Rolno-Spożywczego w Warszawie.

Do badań zastosowano trzy szczepy bakterii kwasu mlekowego: Lactobacillus plantarum SCH1 i Lactobacillus brevis KL5 wyizolowane z surowych wędlin dojrzewających oraz Lactobacillus plantarum S21 wyizolowany z serwatki kwasowej. Szczepy pochodziły z kolekcji mikroorganizmów Zakładu Higieny i Zarządzania Jakością Żywności SGGW i zostały wybrane na podstawie badań Rzepkowskiej i wsp. [39, 40]. Bakterie po namnożeniu w bulionie MRS (Merck, Polska) były odwirowywane w wirówce $(4500 \mathrm{obr} . / \mathrm{min}, 2313 \times \mathrm{g})$ typu J2-21 (Beckman, Dania) po zakończeniu drugiego pasażu i zawieszane w roztworze soli fizjologicznej $(0,9 \%)$. W takiej formie bakterie były wprowadzane do farszów z MDOM. Wariant kontrolny (K) nie zawierał dodatku bakterii kwasu mlekowego. Warianty doświadczalne zawierały dodatek bakte- 
rii: L1 - Lactobacillus plantarum SCH1 w ilości $10^{7} \mathrm{jtk} / \mathrm{g}$, L2 - Lactobacillus brevis KL5 w ilości $10^{7} \mathrm{jtk} / \mathrm{g}$ i L3 - Lactobacillus plantarum S21 w ilości $10^{7} \mathrm{jtk} / \mathrm{g}$.

MDOM z biomasą bakteryjną mieszano w mieszałce (Keripar, USA) przez $3 \mathrm{~min}$ i zamykano w puszki o gramaturze $190 \mathrm{~g} \mathrm{w}$ celu ograniczenia zanieczyszczeń mikrobiologicznych. Następnie puszki przechowywano w temp. $4{ }^{\circ} \mathrm{C}$ przez 7 dni. Badania wykonywano po 1, 4 i 7 dniach chłodniczego przechowywania. W próbkach farszy oznaczano:

- $\quad$ pH [35] elektrodą In Lab Cool (Mettler Toledo, Szwajcaria) i potencjał oksydacyjno-redukcyjny elektrodą InLab Redox Pro (Mettler Toledo, Szwajcaria) w aparacie Mettler Delta 350 (Mettler Toledo, Szwajcaria). Pomiar wykonywano w roztworze przygotowanym przez zhomogenizowanie $10 \mathrm{~g}$ farszu MDOM z $50 \mathrm{ml}$ wody destylowanej w ciągu 1 min przy prędkości noży 14000 obr./min przy użyciu blendera (Bosch, Niemcy),

- zawartość azotanów (III) i (V) [28] z modyfikacją [41] oznaczano przy użyciu modułowego chromatografu cieczowego (Agilent Technologies, Niemcy),

- składowe barwy w systemie CIE L*a*b* - spektrofotometrem odbiciowym Minolta CR-300 (Minolta, Japonia). Pomiar wykonywano przy następujących ustawieniach: obserwator standardowy CIE $2^{\circ}$, iluminant D65, obszar pomiaru $8 \mathrm{~mm}$. Jako źródło odniesienia zastosowano wzorzec bieli $\left(\mathrm{L}^{*}=95,87, \mathrm{a}^{*}=-0,49, \mathrm{~b}^{*}=\right.$ 2,39).

Zakres badań mikrobiologicznych MDOM określano na podstawie badań wstępnych, które obejmowały:

- ogólną liczbę drobnoustrojów w $1 \mathrm{~g}$ (pożywka PCA, inkubacja $30 \pm 1{ }^{\circ} \mathrm{C}, 72 \pm 3 \mathrm{~h}$ ) [30],

- liczbę mezofilnych bakterii fermentacji mlekowej w $1 \mathrm{~g}$ (pożywka MRS, inkubacja $\left.30 \pm 1{ }^{\circ} \mathrm{C}, 72 \pm 3 \mathrm{~h}\right)[33]$,

- liczbę Escherichia coli w $1 \mathrm{~g}$ (podłoże agar TBX, inkubacja $44 \pm 1{ }^{\circ} \mathrm{C}, 18$ - 24 h) [29],

- liczbę Enterobacteriaceae w temp. $37^{\circ} \mathrm{C}$ w 1 g (podłoże VRBD, inkubacja $37 \pm$ $\left.1{ }^{\circ} \mathrm{C}, 24 \pm 2 \mathrm{~h}\right)$ [34],

- obecność Salmonella spp. w 25 g (inkubacja w workach w zbuforowanej wodzie peptonowej (WPZ), $37 \pm 1{ }^{\circ} \mathrm{C}, 18 \pm 2 \mathrm{~h}$. Po inkubacji posiew $0,1 \mathrm{ml}$ do RVS - inkubacja $41,5 \pm 1{ }^{\circ} \mathrm{C}, 24 \pm 3 \mathrm{~h}$ oraz posiew $1,0 \mathrm{ml}$ do MKTT - inkubacja $37 \pm 1{ }^{\circ} \mathrm{C}, 24$ $\pm 3 \mathrm{~h}$. Po inkubacji posiew na pożywki stałe: XLD i RA, inkubacja $37 \pm 1{ }^{\circ} \mathrm{C}, 24 \pm$ 3 h) [31],

- obecność Campylobacter spp. w 25 g (inkubacja w atmosferze mikroaerofilnej w $37 \pm 1{ }^{\circ} \mathrm{C}, 4-6 \mathrm{~h}$, na pożywce płynnej BOLTON. Następnie inkubacja w temp. 41,5 $\pm 1{ }^{\circ} \mathrm{C}, 44 \pm 4 \mathrm{~h}$. Do wykrywania obecności Campylobacter zastosowano szybki test serologiczny Singlepath Campylobacter) [27], 
- liczbę gronkowców koagulazododatnich w $1 \mathrm{~g}$ (pożywka agarowa z plazmą króliczą i fibrynogenem (RPF), inkubacja $37 \pm 1{ }^{\circ} \mathrm{C}, 18$ - $24 \mathrm{~h}$ ) [32].

Do oznaczeń pobierano $10 \mathrm{~g}$ próbki w przypadku oznaczeń ilościowych lub $25 \mathrm{~g}$ w przypadku oznaczeń jakościowych po wymieszaniu produktu i zawieszano w $100 \mathrm{ml}$ wody peptonowej, następnie wykonywano szereg rozcieńczeń i wysiewano na poszczególne podłoża.

W przypadku, gdy w MDOM nie stwierdzono obecności wybranych drobnoustrojów, nie oznaczano ich w dalszym etapie badań przechowalniczych.

Doświadczenia przeprowadzono w trzech równoległych powtórzeniach. Analizę statystyczną przeprowadzono w programie Statgraphics Plus 4.1. Wykonano jednoczynnikową analizę wariancji, a istotność różnic między wartościami średnimi weryfikowano testem Fishera $(\mathrm{p} \leq 0,05)$.

\section{Wyniki i dyskusja}

Wartość pH farszów z mięsa drobiowego oddzielonego mechanicznie (MDOM) była stosunkowo wysoka $(6,70 \div 7,09)$ w porównaniu z mięsem wykrawanym ręcznie, którego pH kształtuje się na poziomie 5,9 $\div$ 6,2 [16]. Ta kwasowość surowca wynikała ze zwiększonej zawartości szpiku kostnego w MDOM pochodzącego ze wstępnie rozdrabnianych kości. Wartość pH szpiku kostnego wynosi 6,8 $\div$ 7,4. Mięso drobiowe oddzielone mechanicznie charakteryzuje pH między 6,5 a 7,0 [47]. Zbliżoną kwasowość MDOM $(6,88)$ wykazali Stangierski i wsp. [42].

Stwierdzono, że pH farszów z MDOM obniżało się podczas chłodniczego przechowywania. Największą dynamikę wzrostu kwasowości farszów z MDOM obserwowano między 1. a 4. dniem przechowywania (tab. 1). Różnice kwasowości farszów z MDOM stwierdzone w poszczególnych okresach przechowywania były niewielkie, choć w niektórych przypadkach statystycznie istotne $(\mathrm{p} \leq 0,05)$. Zastosowanie bakterii kwasu mlekowego wpłynęło istotnie $(\mathrm{p} \leq 0,05)$ na obniżenie $\mathrm{pH}$ po jednym dniu przechowywania w przypadku wariantu L1 ze szczepem Lactobacillus plantarum SCH1 (tab. 1). Po 4 dniach przechowywania we wszystkich wariantach próbek kwasowość farszów z MDOM była zbliżona $(6,79 \div 6,80)$, natomiast po 7 dniach przechowywania najniższe $\mathrm{pH}$ stwierdzono $\mathrm{w}$ farszu L1 z dodatkiem L. plantarum SCH1 $(6,72)$ oraz w wariancie $\mathrm{K}(6,70)$. Biorąc pod uwagę, że stwierdzone różnice $\mathrm{pH}$ między wariantami $\mathrm{w}$ trzech okresach przechowywania były niewielkie $(0,01 \div 0,09)$ można wnioskować, że nie miały one wpływu na przydatność technologiczną farszów w zakresie wodochłonności surowca. 
Tabela 1. Wartości pH i potencjału oksydacyjno-redukcyjnego (ORP) farszów z MDOM podczas chłodniczego przechowywania

Table 1. Values of pH and oxidation-reduction potential (ORP) of MSPM forcemeats during cold storage

\begin{tabular}{|c|c|c|c|c|}
\hline \multirow{2}{*}{$\begin{array}{c}\text { Parametr } \\
\text { Parameter }\end{array}$} & \multirow{2}{*}{ Próba / Sample } & \multicolumn{3}{|c|}{ Czas przechowywania [dni] / Storage time period [days] } \\
\cline { 2 - 5 } & & 1 & 4 & 7 \\
\hline \multirow{4}{*}{ pH } & $\mathrm{K}$ & $7,08^{\mathrm{bC}} \pm 0,02$ & $6,80^{\mathrm{aB}} \pm 0,01$ & $6,70^{\mathrm{aA}} \pm 0,01$ \\
\cline { 2 - 5 } & $\mathrm{L} 1$ & $7,03^{\mathrm{aC}} \pm 0,03$ & $6,79^{\mathrm{aB}} \pm 0,01$ & $6,72^{\mathrm{aA}} \pm 0,01$ \\
\cline { 2 - 5 } & $\mathrm{L} 2$ & $7,08^{\mathrm{bB}} \pm 0,02$ & $6,80^{\mathrm{aA}} \pm 0,01$ & $6,79^{\mathrm{bA}} \pm 0,02$ \\
\cline { 2 - 5 } & $\mathrm{L} 3$ & $7,09^{\mathrm{bB}} \pm 0,02$ & $6,80^{\mathrm{aA}} \pm 0,02$ & $6,78^{\mathrm{bA}} \pm 0,02$ \\
\hline \multirow{3}{*}{$\begin{array}{c}\text { ORP } \\
{[\mathrm{mV}]}\end{array}$} & $\mathrm{K}$ & $324,4^{\mathrm{bA}} \pm 6,6$ & $336,7^{\mathrm{bA}} \pm 8,1$ & $326,6^{\mathrm{bA}} \pm 2,3$ \\
\cline { 2 - 5 } & $\mathrm{L} 1$ & $314,9^{\mathrm{abA}} \pm 5,2$ & $315,3^{\mathrm{aA}} \pm 1,8$ & $313,8^{\mathrm{aA}} \pm 1,2$ \\
\cline { 2 - 5 } & $\mathrm{L} 2$ & $321,3^{\mathrm{bA}} \pm 4,1$ & $317,4^{\mathrm{aA}} \pm 2,9$ & $317,1^{\mathrm{aA}} \pm 1,2$ \\
\cline { 2 - 5 } & $\mathrm{L} 3$ & $304,8^{\mathrm{aA}} \pm 6,0$ & $316,7^{\mathrm{aB}} \pm 0,4$ & $317,4^{\mathrm{aB}} \pm 5,2$ \\
\hline
\end{tabular}

Objaśnienia / Explanatory notes:

$\mathrm{K}$ - próba kontrolna / control sample; L1 - MDOM z Lactobacillus plantarum SCH1 / MSPM with Lactobacillus plantarum SCH1; L2 - MDOM z Lactobacillus brevis KL5 / MSPM with Lactobacillus brevis KL5; L3 - MDOM z Lactobacillus plantarum S21 / MSPM with Lactobacillus plantarum S21. W tabeli przedstawiono wartości średnie \pm odchylenia standardowe / Table shows mean values \pm standard deviations; $\mathrm{n}=3$; $\mathrm{a}, \mathrm{b}$ - wartości średnie $\mathrm{w}$ kolumnach oznaczone różnymi literami różnią się statystycznie istotnie $(\mathrm{p} \leq 0,05) /$ mean values in columns denoted by different letters differ statistically significantly ( $p$ $\leq 0.05)$; A, B, C - wartości średnie w wierszach oznaczone różnymi literami różną się statystycznie istotnie $(\mathrm{p} \leq 0,05) /$ mean values in rows denoted by different letters differ statistically significantly $(\mathrm{p} \leq 0.05)$.

W badaniach Szymańskiego i wsp. [44] obserwowano istotny wpływ wybranych szczepów bakterii kwasu mlekowego na kwasowość farszów z mięsa rozdrobnionego z szynki wieprzowej. MDOM różni się składem chemicznym od mięsa wykrawanego ręcznie. Charakteryzuje się m.in. dużą zawartością thuszczu i kolagenu, a niską aktywnością wody [21, 22, 47]. Można przypuszczać, że środowisko, w którym znalazły się bakterie kwasu mlekowego, było niekorzystne dla ich rozwoju. Stosunkowo mała zawartość cukrów w MDOM mogła mieć również wpływ na ograniczoną produkcję wybranych metabolitów, w tym kwasu mlekowego, przez zastosowane LAB [15].

Podczas całego okresu przechowywania stwierdzono istotny wzrost potencjału oksydacyjno-redukcyjnego tylko w wariancie L3 (o $12,6 \mathrm{mV})(\mathrm{p} \leq 0,05)$. W pozostałych wariantach doświadczalnych średnie wartości potencjału redox nie zmieniły się istotnie $(\mathrm{p}>0,05) \mathrm{w}$ czasie przechowywania, co wskazuje na stabilność oksydacyjną farszów z MDOM. Po 4 i 7 dniach przechowywania w wariantach z dodatkiem bakterii kwasu mlekowego wartość potencjału redoks była na niższym poziomie niż w wariancie K (tab. 1). Podobną zależność wykazali Wójciak i wsp. [48], którzy zastosowali bakterie kwasu mlekowego (L. casei ŁOCK 0900) do kiełbas surowych dojrzewają- 
cych niepeklowanych. Obserwowali niższe wartości potencjału redoks po dojrzewaniu kiełbas w próbach $\mathrm{z}$ dodatkiem $\mathrm{LAB} \mathrm{w}$ porównaniu $\mathrm{z}$ wariantem kontrolnym.

Nie stwierdzono obecności $\mathrm{NaNO}_{3}$ i $\mathrm{NaNO}_{2}$ w farszach z MDOM, co wskazywało na brak zanieczyszczeń surowca tymi związkami. Azotany(V) mogą występować w mięsie przerobowym i kulinarnym, w szczególności wołowym i wieprzowym [7, 9]. Lammarino i Taranto [17] stwierdzili obecność azotanu(V) w mięsie wieprzowym na poziomie $10,2 \div 14,8 \mathrm{mg} / \mathrm{kg}$, a w mięsie wołowym $-10,8 \div 15,0 \mathrm{mg} / \mathrm{kg}$.

W próbie L2, w której zastosowano Lactobacillus brevis KL5, zaobserwowano najwyższy udział barwy czerwonej a* $=22,76 \mathrm{w}$ tonie barwy (tab. 2). Wysoka wartość parametru a* farszu z MDOM (L2) wskazywała na udział L. brevis KL5 w procesach barwotwórczych zachodzących w mięsie. Mogło to być związane $\mathrm{z}$ mechanizmem syntezy NO z L-argininy przez bakterie kwasu mlekowego. Wykazano, że niektóre szczepy bakterii kwasu mlekowego wytwarzają NO poprzez syntezę z L-argininy. W przypadku bakterii tlenek azotu(II) pełni szereg istotnych funkcji - jest cząsteczką sygnałową, aktywuje lub dezaktywuje enzymy. Mechanizm przekształcania L-argininy w przemianach komórki bakteryjnej polega na utlenieniu z udziałem tlenu cząsteczkowego grupy iminowej reszty guanidynowej L-argininy. Reakcja zachodzi dwuetapowo. W pierwszym etapie L-arginina jest hydroksylowana $z$ udziałem tlenu i koenzymu (NADPH), następnie powstały związek pośredni utleniany jest do cytruliny i tlenku azotu. Reakcja katalizowana jest przez kilka izoform enzymu syntazy tlenku azotu [6, 23, 49]. Niektóre szczepy LAB wykazują zdolność do przemiany formy barwnika $\mathrm{z} \mathrm{MbFe}^{3+}$ do $\mathrm{MbFe}^{2+}$, co wpływa na zmianę barwy mięsa surowego niepeklowanego $\mathrm{z}$ brązowej na jasnoczerwoną $[19,50]$.

Najniższy udział składowych barw $\mathrm{a}^{*}=19,45 \mathrm{i} \mathrm{b}^{*}=8,38$ oraz statystycznie istotnie $(\mathrm{p} \leq 0,05)$ najwyższą wartość parametru $\mathrm{L}^{*}=53,88$ (opisującego jasność wyrobu) po 7 dniach przechowywania zaobserwowano w wariancie L1 z Lactobacillus plantarum SCH1. W farszach L1 i L3 po 4 dniach przechowywania jasność L* istotnie obniżyła się, a następnie po 7 dniach przechowywania istotnie wzrosła $(\mathrm{p} \leq 0,05)-$ tab. 2 .

W badaniach wstępnych jakości mikrobiologicznej MDOM wykazano, że surowiec nie spełniał kryterium wymaganego w normie PN-A-86522:1992 [26] pod względem zawartości ogólnej liczby drobnoustrojów (6,30 log jtk/g) oraz obecności pałeczek z grupy coli (liczba Escherichia coli wynosiła 2,04 log jtk/g). Norma dopuszczała ogólną liczbę drobnoustrojów na poziomie $1 \times 10^{6} \mathrm{jtk} / \mathrm{g}$, a pałeczki z grupy coli nieobecne w 0,001 g. W surowcu nie wykryto obecności Salmonella spp. oraz Campylobacter spp., a liczba gronkowców koagulazo-dodatnich wynosiła $<10 \log \mathrm{jtk} / \mathrm{g}$. Ponadto oznaczono liczbę Enterobacteriaceae na poziomie 3,83 log jtk/g. W badaniach wstępnych oznaczono także liczbę mezofilnych bakterii kwasu mlekowego, która wynosiła $4,18 \log \mathrm{jtk} / \mathrm{g}$. 
Tabela 2. Wartości parametrów barwy L* a* b* farszów z MDOM po 1, 4 i 7 dniach przechowywania Table 2. Values of $L^{*} a^{*} b^{*}$ colour parameters of MSPM forcemeat after 1, 4 and 7 days of storage

\begin{tabular}{|c|c|c|c|c|}
\hline \multirow{2}{*}{$\begin{array}{l}\text { Parametr } \\
\text { Parameter }\end{array}$} & \multirow{2}{*}{$\begin{array}{c}\text { Próba / Sample } \\
n=15\end{array}$} & \multicolumn{3}{|c|}{ Czas przechowywania [dni] / Storage time period [days] } \\
\hline & & 1 & 4 & 7 \\
\hline \multirow{4}{*}{$\mathrm{L}^{*}$} & $\mathrm{~K}$ & $51,82^{\mathrm{aA}} \pm 0,68$ & $51,86^{\mathrm{aA}} \pm 0,96$ & $51,59^{\mathrm{aA}} \pm 0,79$ \\
\hline & L1 & $53,95^{\mathrm{cB}} \pm 1,17$ & $52,64^{\mathrm{aA}} \pm 1,27$ & $53,88^{\mathrm{cB}} \pm 1,02$ \\
\hline & L2 & $53,15^{\mathrm{bA}} \pm 1,25$ & $52,36^{\mathrm{aA}} \pm 0,96$ & $53,11^{\mathrm{bA}} \pm 1,27$ \\
\hline & L3 & $55,33^{\mathrm{dC}} \pm 0,77$ & $51,98^{\mathrm{aA}} \pm 1,49$ & $53,16^{\mathrm{bcB}} \pm 0,72$ \\
\hline \multirow{4}{*}{$a^{*}$} & $\mathrm{~K}$ & $18,38^{\mathrm{aA}} \pm 0,75$ & $22,60^{\mathrm{bC}} \pm 1,51$ & $20,22^{\mathrm{abB}} \pm 1,16$ \\
\hline & L1 & $19,74^{\mathrm{bAB}} \pm 1,71$ & $20,76^{\mathrm{aB}} \pm 1,27$ & $19,45^{\mathrm{aA}} \pm 1,10$ \\
\hline & $\mathrm{L} 2$ & $20,39^{\mathrm{bA}} \pm 1,20$ & $20,87^{\mathrm{aA}} \pm 1,55$ & $22,76^{\mathrm{cB}} \pm 1,37$ \\
\hline & L3 & $18,59^{\mathrm{aA}} \pm 1,23$ & $21,49^{\mathrm{aB}} \pm 1,39$ & $20,71^{\mathrm{bB}} \pm 1,02$ \\
\hline \multirow{4}{*}{$b^{*}$} & K & $8,96^{\mathrm{aB}} \pm 0,53$ & $9,29^{\mathrm{aB}} \pm 0,65$ & $8,41^{\mathrm{aA}} \pm 0,87$ \\
\hline & L1 & $9,20^{\mathrm{aB}} \pm 0,52$ & $9,01^{\mathrm{aB}} \pm 0,92$ & $8,38^{\mathrm{aA}} \pm 0,81$ \\
\hline & $\mathrm{L} 2$ & $9,41^{\mathrm{aAB}} \pm 0,72$ & $8,85^{\mathrm{aA}} \pm 0,99$ & $9,60^{\mathrm{cB}} \pm 0,66$ \\
\hline & L3 & $9,02^{\mathrm{aA}} \pm 0,92$ & $9,52^{\mathrm{aA}} \pm 0,53$ & $9,06^{\mathrm{bA}} \pm 0,43$ \\
\hline
\end{tabular}

Objaśnienia jak pod tab. 1. / Explanatory notes as in Tab. 1.

We wszystkich farszach z MDOM w czasie przechowywania obserwowano wzrost ogólnej liczby drobnoustrojów. W przypadku wariantów z dodatkiem bakterii kwasu mlekowego ogólna liczba drobnoustrojów była wyższa z powodu wprowadzenia do farszów z MDOM szczepów LAB (tab. 3).

W farszach, do których wprowadzono LAB (L1, L2, L3), liczba bakterii kwasu mlekowego utrzymywała się na zbliżonym poziomie w całym okresie przechowywania. Podczas przechowywania chłodniczego obserwowano stopniowe hamowanie wzrostu E. coli w farszu L1 z Lactobacillus plantarum SCH1 (tab. 3).

Zastosowanie Lactobacillus plantarum SCH1 wpłynęło również hamująco na rozwój Enterobacteriaceae po 4 dniach przechowywania. Istotnie najniższą liczbę Enterobacteriaceae $(4,56 \mathrm{log} \mathrm{jtk} / \mathrm{g})$ po 4 dniach przechowywania stwierdzono w wariancie L1, w którym zastosowano Lactobacillus plantarum SCH1, natomiast w tym samym czasie w wariancie kontrolnym oznaczono Enterobacteriaceae na poziomie $6,26 \log \mathrm{jtk} / \mathrm{g}(\mathrm{tab} .3)$.

Można przypuszczać, że inhibitujące działanie względem niekorzystnej mikroflory było związane z produkcją bakteriocyn (plantarycyny) i/lub innych metabolitów uwalnianych poza komórkę bakterii [13, 40]. Źródło wyizolowania, jakim było środowisko mięsne, prawdopodobnie miało wpływ na łatwiejszą adaptację Lactobacillus plantarum SCH1 do warunków panujących w farszu z MDOM w porównaniu ze szczepem Lactobacillus plantarum S21 wyizolowanym z serwatki kwasowej. 
Tabela 3. Jakość mikrobiologiczna farszów z MDOM po 1, 4 i 7 dniach chłodniczego przechowywania Table 3. Microbiological quality of stuffings with MSPM after 1, 4 and 7 days of cold storage

\begin{tabular}{|c|c|c|c|c|}
\hline \multirow[t]{2}{*}{ Parametr / Parameter } & \multirow{2}{*}{$\begin{array}{c}\text { Próba } \\
\text { Sample } \\
\mathrm{n}=15\end{array}$} & \multicolumn{3}{|c|}{$\begin{array}{l}\text { Czas przechowywania [dni] } \\
\text { Storage time period [days] }\end{array}$} \\
\hline & & 1 & 4 & 7 \\
\hline \multirow{4}{*}{$\begin{array}{c}\text { Ogólna liczba drobnoustrojów w } \\
\text { temp. } 30^{\circ} \mathrm{C}[\log \mathrm{jtk} / \mathrm{g}] \\
\text { Total bacterial count at } 30^{\circ} \mathrm{C} \\
{[\log \mathrm{CFU} / \mathrm{g}]}\end{array}$} & $\mathrm{K}$ & $6,93^{\mathrm{aA}} \pm 6,07$ & $7,03^{\mathrm{aA}} \pm 6,32$ & $7,99^{\mathrm{aB}} \pm 7,05$ \\
\hline & L1 & $7,94^{\mathrm{dA}} \pm 6,81$ & $8,28^{\mathrm{dB}} \pm 7,00$ & $8,41^{\mathrm{cC}} \pm 7,32$ \\
\hline & L2 & $7,62^{\mathrm{cA}} \pm 6,74$ & $8,01^{\mathrm{cB}} \pm 6,83$ & $8,31^{\mathrm{cC}} \pm 7,61$ \\
\hline & L3 & $7,40^{\mathrm{bA}} \pm 5,76$ & $7,89^{\mathrm{bB}} \pm 6,42$ & $8,27^{\mathrm{bC}} \pm 7,06$ \\
\hline \multirow{4}{*}{$\begin{array}{c}\text { Liczba mezofilnych bakterii } \\
\text { fermentacji mlekowej }[\log \text { jtk/g] } \\
\text { Mesophilic lactic acid bacteria } \\
\text { count }[\log \text { CFU/g] }\end{array}$} & $\mathrm{K}$ & $4,26^{\mathrm{aB}} \pm 3,00$ & $4,07^{\mathrm{bA}} \pm 2,76$ & $4,12^{\mathrm{aA}} \pm 3,46$ \\
\hline & L1 & $7,84^{\mathrm{dA}} \pm 6,75$ & $7,85^{\mathrm{dA}} \pm 6,00$ & $7,78^{\mathrm{cA}} \pm 6,79$ \\
\hline & L2 & $7,37^{\mathrm{cA}} \pm 5,76$ & $7,45^{\mathrm{cB}} \pm 6,30$ & $7,32^{\mathrm{bA}} \pm 6,42$ \\
\hline & L3 & $7,26^{\mathrm{bA}} \pm 0,00$ & $7,28^{\mathrm{bA}} \pm 6,00$ & $7,43^{\mathrm{bB}} \pm 6,18$ \\
\hline \multirow{4}{*}{$\begin{array}{c}\text { Liczba Escherichia coli } \\
{[\log \mathrm{jtk} / \mathrm{g}]} \\
\text { Escherichia coli count } \\
{[\log \mathrm{CFU} / \mathrm{g}]}\end{array}$} & $\mathrm{K}$ & $2,32^{\mathrm{bB}} \pm 1,49$ & $2,32^{\mathrm{bB}} \pm 1,42$ & $<1,00^{\mathrm{aA}}$ \\
\hline & L1 & $2,28^{\mathrm{bC}} \pm 1,30$ & $2,10^{\mathrm{aB}} \pm 1,32$ & $1,94^{\mathrm{bA}} \pm 0,76$ \\
\hline & L2 & $2,03^{\mathrm{aAB}} \pm 1,18$ & $2,09^{\mathrm{aB}} \pm 1,40$ & $1,85^{\mathrm{bA}} \pm 1,30$ \\
\hline & L3 & $2,15^{\mathrm{aB}} \pm 1,24$ & $2,32^{\mathrm{bC}} \pm 1,00$ & $<1,00^{\mathrm{aA}}$ \\
\hline \multirow{4}{*}{$\begin{array}{c}\text { Liczba Enterobacteriaceae } \\
{[\log \mathrm{jtk} / \mathrm{g}]} \\
\text { Enterobacteriaceae count } \\
{[\log \mathrm{CFU} / \mathrm{g}]}\end{array}$} & $\mathrm{K}$ & $3,94^{\mathrm{aA}} \pm 2,67$ & $6,26^{\mathrm{dB}} \pm 5,18$ & $6,61^{\mathrm{aC}} \pm 5,75$ \\
\hline & L1 & $3,94^{\mathrm{aA}} \pm 2,64$ & $4,56^{\mathrm{aA}} \pm 3,58$ & $6,65^{\mathrm{aB}} \pm 5,82$ \\
\hline & L2 & $4,29^{\mathrm{cA}} \pm 3,18$ & $5,94^{\mathrm{bA}} \pm 4,62$ & $6,97^{\mathrm{bB}} \pm 5,88$ \\
\hline & L3 & $4,07^{\mathrm{bA}} \pm 3,06$ & $6,03^{\mathrm{cB}} \pm 4,76$ & $6,63^{\mathrm{aC}} \pm 5,42$ \\
\hline
\end{tabular}

Objaśnienia jak pod tab. 1. / Explanatory notes as in Tab. 1.

Rzepkowska i wsp. [39, 40], w badaniach metodą dyfuzyjno-krążkową na płytkach z selektywnym podłożem, obserwowali wysoką aktywność przeciwdrobnoustrojową szczepów LAB (m.in. L. plantarum SCH1 i L. brevis KL5 oraz L. plantarum S21) w stosunku do E. coli i Pseudomonas fluorescens. Aktywność przeciwdrobnoustrojową zastosowanych szczepów LAB potwierdzono w badaniach własnych na modelowych farszach z MDOM w odniesieniu do E. coli. Po 7 dniach przechowywania w ocenie technologicznej farszów z MDOM stwierdzono nieakceptowany zapach świadczący o zepsuciu surowca. Liczba bakterii $E$. coli w tym czasie była najniższa w każdym z wariantów w porównaniu do liczby tych bakterii po 1 i 4 dniach przechowywania. Zmiany liczby bakterii $E$. coli po 7 dniach przechowywania mogły być spowodowane zdominowaniem mikroflory farszów z MDOM przez inne drobnoustroje obecne w farszach. Wskazywała na to wysoka ogólna liczba drobnoustrojów w tym okresie przechowywania (tab. 3).

Trudno porównywać uzyskane wyniki jakości mikrobiologicznej farszów z wymaganiami normy PN-A-86522:1992 [26], ponieważ nie przewidziano w niej zabezpieczenia surowca $\mathrm{z}$ zastosowaniem bioprotekcji, a wprowadzenie LAB do MDOM spowodowało wzrost ogólnej liczby drobnoustrojów. Po 7-dniowym okresie przecho- 
wywania we wszystkich wariantach z dodatkiem LAB ogólna liczba drobnoustrojów przekraczała granicę dopuszczoną w normie, a liczba E. coli wynosiła 2,09 2,32 log jtk/g (tab. 3). W przypadku bakterii z grupy coli obserwowano stopniową redukcję liczby E. coli w farszu L1, niemniej nie zostało spełnione kryterium założone w normie.

Kolejnym etapem pracy będzie przeprowadzenie badań w kierunku oceny przydatności wybranych szczepów LAB w biokonserwacji farszów z MDOM peklowanych $\mathrm{z}$ zastosowaniem obniżonej dawki azotanu(III) sodu.

\section{Wnioski}

1. Zastosowanie szczepów bakterii kwasu mlekowego w farszach $\mathrm{z}$ mięsa drobiowego oddzielonego mechanicznie nie wpłynęło negatywnie na ich przydatność technologiczną.

2. Zaobserwowano pozytywny wpływ Lactobacillus brevis KL5 na kształtowanie barwy surowych farszów z MDOM.

3. Wykazano hamujący wpływ Lactobacillus plantarum SCH1 na bakterie E. coli oraz Enterobacteriaceae w surowych farszach z MDOM po 4 dniach chłodniczego przechowywania.

4. Przeprowadzone badania wskazują, że wybrane szczepy LAB wyizolowane z produktów pochodzenia zwierzęcego wpływają hamująco na wzrost drobnoustrojów w MDOM.

Badania sfinansowano ze środków statutowych Instytutu Biotechnologii Przemystu Rolno-Spożywczego im. prof. W. Dąbrowskiego w Warszawie.

\section{Literatura}

[1] Angmo K., Kumari A., Savitri M., Bhalla T.Ch.: Antagonistic activities of lactic acid bacteria from fermented foods and beverage of Ladakh against Yersinia enterocolitica in refrigerated meat. Food Biosci., 2016, 13, 26-31.

[2] Balciunas E.M., Martinez F.A.C., Todorov S.D., Gombossy de Melo Franco B.D., Converti A., Pinheiro de Souza Oliveira R.: Novel biotechnological applications of bacteriocins: A review. Food Control, 2013, 32(1), 134-142.

[3] Branscheid W., Judas M., Höreth R.: The morphological detection of bone and cartilage particles in mechanically separated meat. Meat Sci., 2009, 81, 46-50.

[4] Bredholt S., Nesbakken T., Holck A.: Industrial application of an antilisterial strain of Lactobacillus sakei as a protective culture and its effect on the sensory acceptability of cooked, sliced, vacuumpackaged meats. Int. J. Food Microbiol., 2001, 66, 191-196.

[5] Cegiełka A., Kuczyńska N., Pietrzak D.: Zastąpienie surowca wieprzowo-wołowego w kiełbasach homogenizowanych przez mięso drobiowe oddzielone mechanicznie, uzyskane po separacji wysoko- i niskociśnieniowej. Żywność. Nauka. Technologia. Jakość, 2014, 3 (94), 123-135. 
[6] Christensen J.E., Dudley E.G., Pederson J.A., Steele J.L.: Peptidases and amino acid catabolism in lactic acid bacteria. Anton. Leeuw, 1999, 76, 217-246.

[7] Cierach M.: Azotyny w procesie peklowania mięsa - funkcje, aspekty zdrowotne, peklowanie bezazotynowe. Część I. Gospodarka Mięsna, 2007, 59 (4), 24-27.

[8] Daros F.G., Masson M.L., Amico S.C.: The influence of the addition of mechanically deboned poultry meat on the rheological properties of sausage. J. Food Eng., 2005, 68, 185-189.

[9] Duda Z.: Wybrane zagadnienia stosowania azotynu w przetwórstwie mięsa. Żywność. Nauka. Technologia. Jakość, 1998, 3 (16), 5-42.

[10] Dybowski M.: Rynek mięsa drobiowego i jaj. Biuletyn Miesięczny, Instytut Ekonomiki Rolnictwa i Gospodarki Żywnościowej, 2019, 2 (336), 56-61.

[11] Enan G.: Behaviour of Listeria monocytogenes LMG 10470 in poultry meat and its control by the bacteriocin Plantaricin UG 1. Int. J. Poult. Sci., 2006, 5, 355-359.

[12] Food Chain Evaluation Consortium: Study on the monitoring of the implementation of Directive $2006 / 52 / E C$ as regards the use of nitrites by industry in different categories of meat products. Final report, 2016.

[13] Gong H., Meng X., Wang H.: Mode of action of plantaricin MG, a bacteriocin active against Salmonella Typhimurium. J. Basic Microbiol., 2010, 50, 37-45.

[14] Groves K.: Evaluation of simple microscopy protocol for identifying mechanically separated meat in pork, chicken and turkey. Leatherhead Food Res., 2011, 8, 1-52.

[15] Kołożyn-Krajewska D., Dolatowski Z.J.: Probiotic meat products and human nutrition. Process Biochem, 2012, 47, 1761-1772.

[16] Kondratowicz J., Chwastowska-Siwiecka I., Burczyk E., Piekarska J., Kułdo Ż.: Ocena sensoryczna i mikrobiologiczna mięśni piersiowych indyczek w zależności od metody i czasu przechowywania chłodniczego. Żywność. Nauka. Technologia. Jakość, 2011, 3 (76), 143-152.

[17] Lammarino M., Di Taranto A.: Nitrite and nitrate in fresh meats: A contribution to the estimation of admissible maximum limits to introduce in directive 95/2/EC. Food Sci. Technol. Int., 2012, 47, 1852-1858.

[18] Łaszkiewicz B., Szymański P., Kołożyn-Krajewska D.: Problemy jakości mięsa oddzielonego mechanicznie. Med. Weter, 2019, 75 (3), 131-137.

[19] Li P., Luo H., Kong B., Liub Q., Chen C.: Formation of red myoglobin derivatives and inhibition of spoilage bacteria in raw meat batters by lactic acid bacteria and Staphylococcus xylosus. LWT - Food Sci. Technol., 2016, 68, 251-257.

[20] Magda F.: Separatory MOM w przemyśle mięsnym. Gospodarka Mięsna, 2012, 4, 18-22.

[21] Michalski M.: Charakterystyka podstawowego składu mięsa drobiowego uzyskanego z mechanicznego odkastniania. Rocz. Inst. Przem. Mięs., 2006, 56, 67-68.

[22] Michalski M.: Wymagania i ocena jakościowa mięsa oddzielonego mechanicznie otrzymywanego techniką niszczącą oraz techniką nienaruszającą struktury kości. XXXII Dni Przemysłu Mięsnego IBPRS pt. „Postęp w nauce o mięsie i technologii oraz nowe regulacje prawne w przemyśle mięsnym". IBPRS, Warszawa 2009, ss. 6-15.

[23] Morita H., Yoshikawa H., Sakata R., Nagata Y., Tanaka H.: Synthesis of nitric oxide from the two equivalent guanidinonitrogens of L-arginine by Lactobacillus fermentum. J. Bacteriol., 1997, 179 (24), 7812-7815.

[24] Pereira A.G.T., Ramos E.M., Teixeira J.T., Pereira Cardoso G., Ramos A.L.S., Fontes P.R.: Effects of the addition of mechanically deboned poultry meat and collagen fibers on quality characteristics of frankfurter-type sausages. Meat Sci., 2011, 89, 519-525.

[25] Plessas S., Nouska Ch., Karapetsas A., Kazakos S., Alexopoulos A., Mantzourani I., Chondrou P., Fournomiti M., Galanis A., Bezirtzoglou E.: Isolation, characterization and evaluation of the pro- 
biotic potential of a novel Lactobacillus strain isolated from Feta-type cheese. Food Chem., 2007, 226, 102-108.

[26] PN-A-86522:1992. Mięso drobiowe oddzielone mechanicznie.

[27] PN-EN ISO 10272-1:2017-08. Mikrobiologia łańcucha żywnościowego. Horyzontalna metoda wykrywania obecności i oznaczania liczby Campylobacter spp. Część 1. Metoda wykrywania.

[28] PN-EN 12014-3:2006. Artykuły żywnościowe. Oznaczanie zawartości azotanów i/lub azotynów. Część 3. Spektrometryczne oznaczanie zawartości azotanów i azotynów w produktach mięsnych po enzymatycznej redukcji azotanów do azotynów

[29] PN-EN ISO 16649-2:2004. Mikrobiologia żywności i pasz. Horyzontalna metoda oznaczania liczby $\beta$-glukuronidazo-dodatnich Escherichia coli. Część 2 . Metoda płytkowa w temperaturze $44{ }^{\circ} \mathrm{C}$ z zastosowaniem 5-bromo-4-chloro-3-indolilo $\beta$-D-glukuronidu.

[30] PN-EN ISO 4833-1:2013-12. Mikrobiologia łańcucha żywnościowego. Horyzontalna metoda oznaczania liczby drobnoustrojów. Część 1 . Oznaczanie liczby metodą posiewu zalewowego w temperaturze $30^{\circ} \mathrm{C}$.

[31] PN-EN ISO 6579-1:2017-04. Mikrobiologia łańcucha żywnościowego. Horyzontalna metoda wykrywania, oznaczania liczby i serotypowania Salmonella. Część 1. Wykrywanie Salmonella spp.

[32] PN-EN ISO 6888-2:2001. Mikrobiologia żywności i pasz. Horyzontalna metoda oznaczania liczby gronkowców koagulazo-dodatnich (Staphylococcus aureus i innych gatunków). Część 2. Metoda z zastosowaniem pożywki agarowej z plazmą króliczą i fibrynogenem.

[33] PN-ISO 15214:2002. Mikrobiologia żywności i pasz. Horyzontalna metoda oznaczania liczby mezofilnych bakterii fermentacji mlekowej. Metoda płytkowa w temperaturze $30{ }^{\circ} \mathrm{C}$.

[34] PN-EN ISO 21528-2:2017-08. Mikrobiologia łańcucha żywnościowego. Horyzontalna metoda wykrywania i oznaczania liczby Enterobacteriaceae. Część 2. Metoda liczenia kolonii.

[35] PN-ISO 2917:2001. Mięso i przetwory mięsne. Pomiar pH. Metoda odwoławcza.

[36] Pomykała R., Michalski M.: Jakość mikrobiologiczna mięsa drobiowego oddzielonego mechanicznie. Acta Sci. Polonorum, Medicina Veterin., 2008, 7 (4), 43-49.

[37] Pothakos V., Devlieghere F., Villani F., Björkroth J., Ercolini D.: Lactic acid bacteria and their controversial role in fresh meat spoilage. Meat Sci., 2015, 109, 66-74.

[38] Rozporządzenie (WE) nr 853/2004 Parlamentu Europejskiego i Rady z dnia 29 kwietnia 2004 r. ustanawiające szczególne przepisy dotyczące higieny w odniesieniu do żywności pochodzenia zwierzęcego. Dz. U. L 139, ss. 55-205, z 30.04.2004.

[39] Rzepkowska A., Zielińska D., Ołdak A., Kołożyn-Krajewska D.: Organic whey as a source of Lactobacillus strains with selected technological and antimicrobial properties. Int. J. Food Sci. Technol., 2017, 52 (9), 1983-1994.

[40] Rzepkowska A., Zielińska D., Ołdak A., Kołożyn-Krajewska D.: Safety assessment and antimicrobial properties of the lactic acid bacteria strains isolated from Polish raw fermented meat products. Int. J. Food Prop., 2017, 20 (11), 2736-2747.

[41] Siu D., Henshall A.: Ion chromatographic determination of nitrate and nitrite in meat products. J. Chromatog., 1998, 804, 156-160.

[42] Stangierski J., Baranowska H.M., Rezler R., Kijowski J.: Enzymatic modification of protein preparation obtained from water-washed mechanically recovered poultry meat. Food Hydrocolloid, 2008, $22,1629-1636$.

[43] Szymański P., Łaszkiewicz B.: Problemy w identyfikacji mięsa oddzielonego mechanicznie. Gospodarka Mięsna, 2017, 12, 30-36.

[44] Szymański P., Łaszkiewicz B., Maszewska A., Kern-Jędrychowski J., Moch P.: Sprawozdanie z realizacji tematu BST o symbolu: 500-01-ZMT-03 pt. Wpływ wybranych szczepów bakterii denitryfikujących i kwasu mlekowego zastosowanych w procesie peklowania mięsa $\mathrm{z}$ obniżoną dawką 
azotanu(III) sodu na wybrane cechy jakościowe modelowego produktu mięsnego poddanego obróbce cieplnej. Warszawa 2017.

[45] Thielke S., Lhaft S.K., Kühne M.: Effects of aging prior to freezing on poultry meat tenderness. Poul. Sci., 2005, 84 (4), 607-612.

[46] Tolik D., Słowiński M., Desperak K.: Wpływ zastosowania drobiowego mięsa oddzielonego mechanicznie oraz mięsa odścięgnionego na jakość pasztetów sterylizowanych. Żywność. Nauka. Technologia. Jakość, 2015, 5 (102), 132-141.

[47] Trindade M.A., de Felício P.E., Castillo C.J.C.: Mechanically separated meat of broiler breeder and white layer spent hens. Sci. Agric. (Piracicaba, Braz.), 2004, 61 (2), 234-239.

[48] Wójciak K.M., Dolatowski Z.J., Kołożyn-Krajewska D.: Stabilność oksydacyjna ekologicznej kiełbasy surowo dojrzewającej z dodatkiem probiotycznego szczepu Lactobacillus casei ŁOCK $0900 \mathrm{i}$ serwatki kwasowej. Żywność. Nauka. Technologia. Jakość, 2014, 2 (93), 93-109.

[49] Wójciak K.M., Dolatowski Z.J.: Effect of acid whey on nitrosylmyoglobin concentration in uncured fermented sausage. LWT - Food Sci. Technol., 2015, 64, 713-719.

[50] Zhang X., Kong B., Xiong Y.: Production of cured meat color in nitrite-free Harbin red sausage by Lactobacillus fermentum fermentation. Meat Sci., 2007, 77, 593-598.

\section{EFFECT OF SELECTED LACTIC ACID BACTERIA ON PHYSICOCHEMICAL CHARACTERISTICS AND MICROBIOLOGICAL QUALITY OF MECHANICALLY SEPARATED POULTRY MEAT}

S u m m a r y

The objective of the research study was to assess the effect of selected lactic bacteria strains on the technological usefulness and microbiological stability of mechanically separated poultry meat (MSPM).

The experimental material consisted of mechanically separated poultry meat (MSPM); to the MSPM analysed, there were added three strains of lactic acid bacteria at a level of $10^{7} \mathrm{CFU} / \mathrm{g}$ (Lactobacillus plantarum SCH1 and Lactobacillus brevis KL5 isolated from raw ripened cured meat and Lactobacillus plantarum S21 isolated from acid whey). The control variant did not contain any bacteria added. Forcemeats made of MSPM were stored under the refrigeration conditions and tested after 1, 4 and 7 days of storage. The scope of the study included the determination of the following: total count of microorganisms, count of mesophilic lactic bacteria, counts of Escherichia coli and Enterobacteriaceae, presence of Salmonella spp., presence of Campylobacter spp. and count of coagulase-positive staphylococci; furthermore, the physicochemical characteristics were determined: $\mathrm{pH}$ and oxidation-reduction potential, content of nitrate (III) and (V); the colour of the forcemeat was assessed using a CIE L*a*b* scale. The lactic acid bacteria strains added to forcemeats made of mechanically separated chicken meat did not adversely affect their technological suitability. A positive effect was reported of Lactobacillus brevis KL5 on the colour development of raw forcemeats of MSPM. It was shown that Lactobacillus plantarum SCH1 had an inhibitory effect on E. coli and Enterobacteriaceae in raw forcemeats of MSPM after 4 days of refrigerated storage. The research conducted makes it possible to conclude that the selected LAB strains isolated from animal products inhibit the growth of microorganisms in MSPM.

Key words: mechanically separated poultry meat (MSPM), technological usefulness of MSPM, lactic acid bacteria, microbiological quality of MSPM 